\title{
The Nation as Hegemonic Project
}

Final Version for Journal of Political Ideologies, March 22, 2017

\begin{abstract}
This article argues that the nation is best conceived as a hegemonic project. It starts with a discussion of the dialectical intertwining of the categories of nationhood and nationalism, and continues with a treatment of the analytical distinction and historical relationship between states and nations. It sketches the rise of and problems with the principle and practice of "self-determination" in the post-Wilsonian world, and seeks to problematize still-influential Leninist-cum-Stalinist dogmas regarding the "selfdetermination" of nations. It concludes with an extended consideration of Benedict Anderson's sophisticated neo-Marxist apology for nationalist politics and ideology. It takes Anderson to task on three related counts: for paying insufficient attention to power relations; for underestimating the affinities between nationalism and racism; and for denying the intimate connection between nationalism and fascism.
\end{abstract}

Keywords: nationalism, state-building, nation-building, self-determination, mystification, fascism

\section{Introduction}

This article argues that the nation is best conceived as a hegemonic project. It starts with a discussion of the dialectical intertwining of the categories of nationhood and nationalism, and continues with a treatment of the analytical distinction and historical relationship between states and nations. It draws on and synthesizes the important work of Juan Linz and Eric Hobsbawm, paying particular attention to the processes of state-building and nation-building in the European "core" of the emergent world system.

The article then turns to discuss the rise of and problems with the doctrine and practice of "self-determination" in the post-Wilsonian world. It seeks to problematize stillinfluential Leninist-cum-Stalinist dogmas regarding the "self-determination" of nations. It briefly revisits and recovers alternatives to the Leninist position within the classical Marxist tradition. More substantially, it returns to Marx himself. It focuses on Marx's early writings, 
especially "On the Jewish Question," emphasizing the problematic of "demystification." The article concludes with an extended consideration of Benedict Anderson's sophisticated neoMarxist apology for nationalist politics and ideology. It takes Anderson to task on three related counts. First, it chides Anderson for paying insufficient attention to power relations specifically, for ignoring the ways in which all appeals to national community and national belonging are embedded within concrete struggles to reproduce or transforming existing constellations of power. Second, it chastises Anderson for underestimating the affinities between nationalism and racism in his attempt to decouple the emotions of love and hate, not to mention the discourses of destiny and contamination. Finally, it invokes Benjamin and Buck-Morss, in providing grounds for scepticism against Anderson's attempt to distance nationalism from fascism.

\section{Nationhood and Nationalism}

In ontological terms, the "nation" is best conceived as a hegemonic project. ${ }^{1}$ It exists only insofar as people believe it does. This does not mean that the nation should be equated with an ethereal "system of ideas," nor relegated to the super-structural realm, much less diagnosed or dismissed as a form of "false consciousness." For to do so would entail perpetuating a false binary between materialism and idealism, between base and superstructure. ${ }^{2}$ Like any other idea, the "nation" can only exist as a material force in history, "embodied in institutions and apparatuses" - in other words, as "institutionalised form." ${ }^{3}$

Nationalists aspire for their beliefs to be institutionalized, so that such beliefs can be diffused, adhered to by an ever broader public, and reproduced. The process of diffusion and 
reproduction of nationalist beliefs by state apparatuses has been described in architectural terms as that of "nation-building." ${ }^{\text {"4 }}$ More recently, Brubaker has described state apparatuses engaged in such processes as "nationalizing states." He refers to "nationalization" and to "nationalizing nationalisms of the existing state" and to "nationalizing elites." 5 Nationhood and nationalism are dialectically interrelated. Gellner has famously insisted that "[i]t is nationalism which engenders nations, and not the other way around." 6 It is certainly true that nationalists aspire for their beliefs to be institutionalized, so that such beliefs can be diffused, adhered to by an ever broader public, and reproduced. Nevertheless, Gellner's formulation is not quite correct; for nationhood and nationalism cannot be neatly distinguished in terms of cause and effect (at least not when these terms are used in a unidirectional and undialectical way). Rather than fixating on questions about which determines the other, about which comes first (the "chicken or the egg," so to speak), it makes more sense to understand nationalism and nationhood as two dimensions of the same inter-subjective phenomenon, operating simultaneously at different levels of consciousness - corresponding with the "programmatic" and the "banal."7

Nationalism operates primarily at the conscious level, manifesting itself as "ideology" - at its core, a political program that "holds that the political and the national unit should be congruent." $^{8}$ Nationhood, by contrast, operates principally at the semi- and even subconscious levels, as a "pervasive system of social classification," an organising "principle of vision and division' of the social world." 9

The literature on "nation-building" provides the tools for sketching the blueprint of institutional arenas targeted by "nationalizing elites," as well as of the institutional contexts within and against which these elites operate. However, it does not provide much in the way 
of tools for accounting for how or why particular "nationalizing elites" come to capture state power, much less how or why particular nationalizing projects eventually succeed or fail. In other words, it is insufficient for understanding how and why the blueprints of particular nationalizing projects come to be "built," converted into intersubjective common sense, i.e. social reality, whilst others are defeated entirely, or at least relegated to the margins. To answer such broader questions about the political dynamics propelling processes of "nationbuilding," recourse to the concept and theory of hegemony is required. ${ }^{10}$

The relation between nationhood and nationalism can be usefully compared to Marx's important distinction between class-in-itself and class-for-itself. In making this distinction, Marx implies an "objective existence to class structure independent of actors' awareness."11 Strictly speaking, such an implication is mistaken. Like all groups capable of exercising collective agency, classes are intersubjective, not objective, realities - at least in the first instance. Moreover, they operate at three, not two, dialectically interrelated levels (or "analytical moments"): (1) as cultural rules; (2) as emergent material relations; and (3) as situated human behaviour and self-understanding.

Yet Marx's dichotomy between class-in-itself and class-for-itself remains nevertheless instructive. For class relations "may exist objectively without actors' being aware of them" (even if it is also true that they can only exist "if actors are doing something of which they are aware"). ${ }^{12}$ In this respect, the ontology of nationhood is fundamentally different from that of class - except to the extent that nationhood is effectively fused with the state. ${ }^{13}$

\section{Nation and State}


"Nation" and "state" are two categories all too often conflated in common parlance and even in scholarly debate. Yet, as Juan Linz has incisively argued, "state-building and nation-building are two overlapping but conceptually and historically different processes." ${ }^{14}$ Conceptually, following Rokkan, the term "state refers to the sphere of highest governmental authority and administration." The emergence of the so-called "modern state is synonymous with the gradual concentration of administrative functions in the hands of the central government." In the Medieval Kingdoms of Europe, by contrast, "the ruler possessed the highest authority but controlled only his own domains."15 The process of state-building thus refers to the encroaching concentration of power, more concretely the shift towards a monopoly of administration and coercive force in the hands of the sovereign, in a word, the trend towards absolutism. ${ }^{16}$ Historically, this state-building process can be traced back - at least in the European core of the emergent world capitalist system - to the "crisis of feudalism, the Rennaissance, and the Reformation," and more specifically, to "rivalries between emerging monarchies in Western and later Northern Europe."17

By contrast, the term "nation" has proven notoriously hard to define. The dominant definitional trope today is that a nation is a particular type of "imagined" political community. Indeed, according to Benedict Anderson's highly influential account, the "nation" is a community imagined as both sovereign and limited. ${ }^{18}$ However, this definition remains too abstract. In the concrete world, as Hobsbawm perspicaciously lamented, "no satisfactory criterion can be discovered for deciding which of the many human collectivities should be labelled in this way." To begin with, because there is no objective "way of telling the observer how to distinguish a nation from other entities a priori, as we can tell him or her how to recognize a bird or to distinguish a mouse from a lizard" (or for that matter an NGO from a 
state).${ }^{19}$ Consequently, all "objective" definitions of the nation not only "have failed" but are bound to fail. Worse yet, the "subjective" alternative of defining the nation in terms of the existence of national consciousness is perhaps more problematic still - open to the objections of tautology and extreme voluntarism. ${ }^{20}$

Max Weber considered the term nation to belong to the sphere not of "facts" but of "values." According to Weber, the nation "means above all else that it is proper to expect from certain groups a specific sentiment of solidarity in the face of other groups." 21 Otherwise put, the term nation is never simply descriptive; instead, it entails, at least implicitly, an imperative of sacrifice, solidarity and ultimate political loyalty. Yet, in the sphere of "facts," similar to Hobsbawm, "Weber also notes, there is no agreement on how these groups should be delimited or about what concerted action should result from such solidarity."22

Whereas the term "state" is both a category of praxis and a category of analysis, the term "nation" is best considered a category of praxis alone. The state "involves a series of offices ... highly differentiated in modern bureaucracies, armies, courts of justices, legislatures, etc." The nation does not - "[t]here are no clear rules about membership in a nation and there are no defined rights and duties that can be legitimately enforced." ${ }^{23}$ This is the persuasive core of Brubaker's call to reframe the study of nationalism so that it overcomes the insidious propensity to rely upon and reify the category of the nation.

As an historical process, state-building preceded the emergence of specifically "national" consciousness by several centuries. For hundreds of years, "state-building went on without being based on national sentiment, identity, or consciousness." Only in the nineteenth century, would the idea of the nation begin to "fire the imagination of the intellectuals and the people."24 
From early on, "architectonic images" were invoked to describe the state-building process. Indeed, the state was long associated "with the ideas of creation and craft." To this day, the category "state" continues to connote "artefact," not "nature," or "organic birth," the way the category of "nation" does.

If "states" and "nations" are thus imagined quite differently, this is closely related to the relative newness of the "nation." When states first began to emerge from the fifteenth century, they "did not require intense identification of their subjects with territorial boundaries, history, culture, or language." In fact, "state identification and loyalty were often expected to be transferable merely by virtue of dynastic marriages. That is, loyalty belonged to the dynasty, not to the nation." 25

The Enlightenment and especially the French Revolution brought with them a profound and radical alteration of the terms of political legitimation across much of the continent, in turn both reflecting and propelling forward underlying transformations in the contours of social-property relations. ${ }^{26}$ The era of the "nation-state" commenced, and with it, sovereignty came to rest - at least in the realm of dominant social imaginaries - no longer in "divinely-ordained, hierarchical dynasties," but instead, in the horizontally-conceived, secular and general will of the third estate, i.e. "the nation." ${ }^{27}$ In Hobsbawm's formulation, the nation "is a social entity only insofar as it relates to a certain kind of modern territorial state, the 'nation-state', and it is pointless to discuss nation and nationality except insofar as both relate to it." 28

Over the course of the nineteenth century and especially in the early twentieth century, the categories of "nation" and "state" would be progressively fused in the core of the capitalist world system, as the rulers of many states chose to pursue deliberate "nation- 
building" policies. The state made the nation, and it did so because it needed to. ${ }^{29}$ Accompanying and in order to spur on the radical social transformations wrought by industrialization, the state expanded its reach substantially, descending down from commanding heights into the "everyday life" of its subjects, "through omnipresent agents, from postmen and policemen to teachers and (in many countries) railway employees." Creeping democratization, and the incipient demise of "traditional religion as an effective guarantee of social obedience," rendered it imperative for state authorities to rely upon a new "way of welding together the state's subjects against subversion and dissidence." Enter the nation: "the new civic religion of states," a "cement which bonded ... citizens to their state." The more democracy advanced, "the more masses were drawn into politics by elections," and in turn, "the more scope there was for" appeals to the nation "to be heard." 30

With technological advances, the administration of the state and the economy, both public and private, came to require mass literacy, and this in turn triggered the trend of linguistic assimilation into a national lingua franca. Education and conscription were what turned "peasants into Frenchmen," to invoke Eugen Weber's felicitous turn of phrase. ${ }^{31}$ But such deliberate pursuit of "nation-building" policies rarely proved so successful outside of France; for state nationalism "was a double-edged strategy," and though it proved capable of mobilizing some inhabitants, it simultaneously "alienated others - those who did not belong, or wish to belong, to the nation identified with the state." ${ }^{32}$

The link Hobsbawm makes between "nationalization" and "democratization" is most insightful. Elsewhere he has famously equated "the age of democratization" with the "era of public political hypocrisy."33 For Hobsbawm, "nationalism" is a classic case of such hypocrisy. An ideology capable of manipulating the masses - more often than not - for the benefit of 
the few. The First World War, at least as much as the Second, reveal it as a most dangerous ideology, a most potent concoction and useful tool for manipulating the masses, a belief system that renders them willing to slaughter one another, all for sake of country.

Education for the purposes of creating a literate and nationalized pool of labor, recruitment into war machines capable of mobilizing masses for suicidal sacrifice in total war - these are the motives and mechanisms that underpinned and propelled forward the "nationalization" of the masses throughout much of Europe. ${ }^{34}$ "Nationalization" and statepropagated nationalisms were thus the products of deliberate decisions made by European rulers commanding rival ships of state across the tormentuous seas in an era marked by creeping democratization, capitalist and Imperialist expansion, and looming Inter-Imperialist War. $^{35}$

\section{The Rise of the Principle of "National Self-Determination"}

The so-called "Great War" was a crucial turning point. President Wilson famously insisted at the peace settlement in 1918 that "[n]ational aspirations must be respected; people may now be dominated and governed only by their own consent," and that "[s]elf-determination is not a mere phrase; it is an imperative principle of action." Woodrow Wilson, the man who posed as the great liberator of the nations, himself a staunch nationalist of an unequivocally imperialist, even messianic, bent; an eloquent propagandist of the vision of the United States as a chosen people, a new Jerusalem, a city on the hill: "We are chosen and prominently chosen to show the way to the nations of the world." ${ }^{\prime 36}$ 
In the post-Wilsonian world, the doctrine of self-determination is commonly conceived as holding that "the political and the national unit should be congruent." 37 However, when it first burst on to the historical stage at the time of the French Revolution, the ideal of self-determination "implied primarily the right of peoples to constitute national states in defiance of the dynastic principle, and was a domestic as well as an international question. It certainly did not contemplate a wholesale process of secession and disintegration." 38 The so-called "springtime of the peoples" of 1848, inflected as it was with the ideological currents of romanticism, marked a decisive turning point in the history of the doctrine, a transformation from a claim about sovereignty residing in "the people, not the monarch" into a claim about the right of particular nationalities, increasingly imagined along Herderian volk-ish lines, to their own independent states. ${ }^{39}$

Indeed, German thinkers like Fichte and Herder developed an idea of the "nation" which was originally used "to appeal across the boundaries of existing states to achieve the unification of people of the same language and culture." 40 This was the moment of birth of nationalism as a political movement in Europe. At the time of the 1848 revolution, nationalist agitation was "strongly linked with liberal and democratic movements" against the monarchical states, and nationalist ideology was epitomized by radical democrats "like Garibaldi and Mazzini who hoped to combine liberal democratic and republican goals with nationalism." But slowly "nationalism came to take precedence over liberal democratic ideas," and radical democrats like Garibaldi and Mazzini gave way to conservative nationbuilders such as Bismarck and Cavour. ${ }^{41}$

It would not be until the end of the First World War, however, that the nationalist version of the principle of national self-determination would reach its apogee in legitimating 
the reconfiguration of state boundaries across the European continent, in accordance with the Wilsonian principle. ${ }^{42}$ It is worth remembering, however, that the attempt to apply this principle - that is, the attempt "to make state frontiers coincide with the frontiers of nationality and language" - in inter-war Europe proved utterly impractical. Indeed, it proved ultimately disastrous, as Hobsbawm rightly insists:

\begin{abstract}
"Inevitably, given the actual distribution of peoples, most of the new states built on the ruins of the Old Empires, were quite as multinational as the old 'prisons of nations' they replaced. Czechoslovakia, Poland, Romania and Yugoslavia are cases in point. German, Slovene, and Croat minorities in Italy took the place of Italian minorities in the Habsburg Empire. The main change was that states were now on average rather smaller and the 'oppressed peoples' within them were now called 'oppressed minorities'. The logical implication of trying to create a continent neatly divided into coherent territorial states each inhabited by a separate ethnically and linguistically homogenous population, was the mass expulsion or extermination of minorities. Such was and is the murderous reducto ad absurdum of nationalism in its territorial version, although this was not fully demonstrated until the 1940s." 43
\end{abstract}

Nor can the disastrous outcome of the attempt to apply the principle of selfdetermination in inter-war Europe be dismissed as a mere contingency or freak mistake. Rather, it should be recognized as illustrative of the highly divisive and polarizing populist potential of rendering salient rival ethno-nationalist territorial claims in complexly intertwined demo-scapes of linguistic and cultural diversity. The aspirations of rival contending ethno-national groups simply cannot be fulfilled simultaneously. The victories of the utopian dreams of some necessarily require the defeats of the dreams of others. ${ }^{44}$

Despite this fundamental problem inherent in the Wilsonian principle of national selfdetermination, the doctrine nevertheless remains at the core of current nationalist mobilization throughout much of the world. ${ }^{45}$ However, the appeal of the doctrine cannot be attributed to the pernicious legacy of President Wilson alone. Indeed, Wilson's beliefs about self-determination would surely not be nearly so influential to this day if it were not for their paradoxical convergence with the ideas of Vladimir Lenin as well as - in no small part through 
the influence of the Bolshevik party line - their subsequent salience in the struggles against oppression throughout the colonial world. ${ }^{46}$

Wilson himself never intended the doctrine to apply to colonial possessions beyond the "mature" nations of Europe. It was Lenin who first made that connection - advocating the doctrine of national self-determination in the struggles against Czarist Russia as well as in struggles of colonized populations for "national liberation" outside of Europe. The particular tactical judgment behind his advocacy for such a universal principle: the consideration "that the liberation of oppressed colonial peoples was an important potential asset for world revolution." ${ }^{\prime 47}$

It should not be forgotten that “Lenin's early enthusiasm for the potential revolutionary role of nationalism in colonial and non-colonial areas," reflected in "his fervent advocacy of the slogan of national self-determination after 1914," was highly controversial in Marxist circles at the time. ${ }^{48}$ To begin with, it brought him into direct confrontation with AustroMarxists such as Karl Renner and Otto Bauer, who remained committed to balancing the struggle against "national oppression" with a clear-cut rejection of territorial appeals for the disintegration of the Austro-Hungarian multi-national state along national lines. ${ }^{49}$ It also brought him into sharp conflict with Rosa Luxemburg, who in the course of debates over the fate of Poland had attacked the bourgeois principle of self-determination for its "abstract" and "utopian" character, dismissing it in no uncertain terms:

The formula, "the right of nations to self-determination" ... gives no practical guidelines for the day to day politics of the proletariat, nor any practical solution of nationality problems. For example, this formula does not indicate to the Russian proletariat in what way it should demand a solution of the Polish national problem, the Finnish question, the Caucasian question, the Jewish, etc. ... The duty to resist all forms of national oppression does not include any explanation of what conditions and political forms the class-conscious proletariat in Russia at the present time should recommend as a solution for the nationality problems of Poland, Latvia, the Jews, etc., or what program it should present to match the various programs of the bourgeois, nationalist, and 
pseudo-socialist parties in the present class struggle. In a word, the formula, "the right of nations to self-determination," is essentially not a political and programmatic guideline in the nationality question, but only a means of avoiding that question." ${ }^{50}$

Indeed, Lenin's position on national self-determination was originally sharply contested even amongst fellow Bolsheviks who, "like most radical Marxists, rejected appeals to nationalism as inappropriate and un-Marxist." In this vein, in 1915, Bukharin, Piatokov, and Bosh sent documents to the Central Committee attacking Lenin's slogan of "selfdetermination" as "first of all utopian ... and harmful as a slogan which disseminates illusions." 51

Lenin's initially contentious position on self-determination would be elaborated, at his behest, by the young Stalin and eventually rendered hegemonic among the Communist left, due to its institutionalization in the Soviet Union at the level of Bolshevik party program and Constitutional principles, if clearly not always in state practice. ${ }^{52}$

\section{Returning to Marx and Engels on the National Question}

Marxism-Leninism has thus been complicit in the reification of the nation-form and of nationalism as a dominant ideology. However, the desacralization of Lenin allows in principle for a return to origins of sorts within the Marxist tradition, opening up space for questioning and re-evaluating old Leninist dogmas. Among these, the dogma about national selfdetermination. ${ }^{53}$ At first blush, this task may seem difficult, since it has often been alleged that the founding fathers of historical materialism had surprisingly little to say about nationalism at the level of theory, and that they underestimated the strength of its appeal at the level of practice. ${ }^{54}$ In this vein, Pelczynski complains that "[t]hey had no explanation, for instance, of why Polish patriotism in the nineteenth century was so intense and manifested 
itself in frequent uprisings against foreign powers, although they noted it and praised it often in their writings," before posing the question: "How could Marx, who was such an acute observer of contemporary history as well as a social theorist of genius, have been so theoretically unconcerned about one of the dominant political phenomena of nineteenthcentury Europe, and apparently blind to its significance for world history?"155

There is some truth in this accusation. Marx and Engels did, after all, famously and falsely diagnose in their Communist Manifesto - a document drafted in response to the socalled "springtime of the peoples" of 1848 - that "national differences and antagonisms are daily more and more vanishing, owing to the development of the bourgeoisie, to freedom of commerce, to the world-market, to uniformity in the mode of production and in the conditions of life corresponding thereto." 56 Indeed, they even went so far as to insinuate that the dialectical development of the laws of capitalism was leading to an immanent transcendence of "national culture" and "national consciousness" and the emergence a world culture alongside an international revolutionary class consciousness. In terms of the immanent transcendence of national culture and its replacement with world culture, they described/predicted:

\footnotetext{
"In place of old local and national seclusion and self-sufficiency, we have intercourse in every direction, universal inter-dependence of nations, and as in material, so also in intellectual production. The intellectual creations of individual nations become common property. National one-sidedness and narrow-mindedness become more and more impossible, and from the numerous national and local literatures there arises a world literature." ${ }^{57}$
}

It must be recalled, however, that the Communist Manifesto was a pamphlet drafted in a hurry, as a programmatic, even propagandistic, call to action in response to rapidly developing revolutionary tumult. It was thus intended as a direct public intervention in an on-going political struggle, in which Marx and Engels were explicitly concerned to steer events 
- in accordance with a roadmap they drew, a roadmap for worldwide revolutionary rupture, expected to erupt in and spread out from the capitalist core. Given the nature of the revolutionary tumult to which they were responding, they were of course well aware of the mobilizational power and popular appeal of the category of the "nation," of its links to struggles for the establishment of bourgeois freedoms in bourgeois republics. Indeed, their document makes explicit appeal across national boundaries to all workers of the world. In their call for all workers to unite, justified by their claim that "workers have nothing to lose but their chains," Marx and Engels are deliberately attempting to counter the emergent hegemony of the category of "nation." They do so by articulating an alternative discourse, one that advocates and foresees a more fundamental revolutionary rupture, a transformation of social-property relations, to be protagonized by the toilers of humanity themselves, destined to unite across national boundaries to struggle against their common lot of misery and exploitation. ${ }^{58}$

It is not fair to consider Marx and Engels naïve on the national question. ${ }^{59}$ For starters, especially in the longer term, as Eric Hobsbawm not so long ago reminded us, the expansion of capitalist social-property relations across the globe has indeed created something approximating the "world culture" prophesied in the Manifesto by the founding prophets of the faith in communism. ${ }^{60}$ However, the emergence of this "world culture" has only on rare occasions entailed a transcendence of "national" modes of identification, perhaps even especially among the working class. But Marx and Engels then believed the onset of global revolution to be immanent; and they believed as well that along with the immanent realization of human emancipation would come the transcendence of the national "webs of 
mystification," as well as the religious ones, in which the consciousness of the workers remained for the time being, unfortunately all too often enmeshed.

Because Marx and Engels were confident that such national and religious webs of mystification were destined to soon be washed away by the rising tide of human emancipation and the wave of global communist revolution, they spent little time inquiring into the institutional mechanisms of entrenchment and reification of sometimes conflicting, always ethno-fetishized and particularistic, national modes of consciousness. But alas, the global revolutionary rupture that Marx and Engels thought was immanent never arrived. Instead, the revolutionary tumult of mid-century Europe would soon give way to a quarter century of political stability underpinned by unprecedented capitalist expansion, and then increasing competition among rival capitalist powers, culminating in an Imperial scramble for Africa and ultimately the outbreak of World War. ${ }^{61}$

Moreover, when communist revolution finally broke out, nearly seventy years after Marx and Engels had declared its arrival immanent, it erupted not in the capitalist core of Europe but instead in the Eurasian periphery, when the Bolsheviks seized power in defeated Czarist Russia. The coming to power of revolutionary forces in Russia was immediately hailed by many Marxists in the West as harbinger and trigger of immanent world revolution, and indeed was theorized as such by the Bolshevik leaders Lenin and Trotsky as well. ${ }^{62}$ But alas, again, the immanent world revolution never came. The revolution failed to spread from the periphery to the capitalist core, and with this failure, the strategy of "socialism in one country" was over-determined, as perhaps was even the tragic denouement of Stalinist tyranny that ended up extinguishing the emancipatory flame lit in October of $1917 .{ }^{63}$ 
Though the founding fathers of historical materialism did not spend much time inquiring into the mechanisms of entrenchment and reification of national modes of consciousness, it is a mistake to claim that they were "theoretically unconcerned" with the phenomenon of nationalism. However, to understand their theoretical posture towards the phenomenon requires coming to grips with their critique of "political emancipation" as such. In this regard, it must be recalled that Marx developed his unique approach to social analysis originally as an internal critique of liberalism: indeed, Marxism grew out of, was born of, such an exercise of ruthless but immanent critique. In two important early writings from the mid-1840's, on the eve of his decisive break with the categories of liberal philosophy and classical political economy, Marx would elaborate a set of weighty theoretical considerations sufficient (1) to conclude that the legal and political theories of liberalism were inadequate for understanding social reality, and (2) to dismiss the conflation between "political emancipation" and "human emancipation" upon which any project of "national liberation" ultimately depends.

\section{The Continuing Relevance of Marx on the Jewish Question}

In a word, by the mid-1840s, Marx had come to believe that socialism would necessarily entail "the full emancipation of the individual from the web of mystification which turned community life into a world of estrangement presided over by an alienated bureaucracy." 64 Furthermore, among this "web of mystifications" that needed to be destroyed, Marx had surmised, were situated "not only those bonds rising out of class division and exploitation, but also religious and national ties." ${ }^{65}$ 
In "On the Jewish Question," Marx confronted head-on a question that is intimately related to debates about the "nation" and "national liberation": that of the extension of the franchise in Germany to a minority, a religious-cum-ethnic minority. The essay takes the form of a critique of Bruno Bauer's analysis of the problem, in which Bauer had urged that the franchise be extended to the Jews. Bauer had advanced a classic liberal argument: the problem defined as some group being denied its rights; the solution, an extension of equality. In fact, Bauer had gone one step further than this classic liberal argument - he maintained that the Jewish question posed the larger problem of the relations between religion and the state, both exposing the hypocrisy of the "so-called Christian state" while demanding "that the Jew should renounce Judaism, and in general that man should renounce religion, in order to be emancipated as a citizen." ${ }^{66}$ However, Bauer continued to think the problem could be solved from within the existing political institutions. By contrast, Marx expands the problem further, posing a third question, above and beyond the questions, 'Who should emancipate?' and 'Who should be emancipated?'. Marx asks: What kind of emancipation is involved?

It is at this point where the distinction between "political emancipation" and "human emancipation" comes to the foreground. Marx insists: "To be politically emancipated from religion is not to be finally and completely emancipated from religion, because political emancipation is not the final and absolute form of human emancipation." ${ }^{67}$ He adds that "one should have no illusions about the scope of political emancipation," and proceeds to elaborate a sophisticated denunciation of the alienated, bifurcated double-consciousness and indeed double-existence that almost inevitably permeates the subjectivities and configures the concretely unfree life-circumstances of politically emancipated but actually subjugated 
citizens. Indeed, Marx describes the contradiction between formal freedom and actual subjugation in nothing short of biblical terms:

\begin{abstract}
"Where the political state has attained its true development, man - not only in thought, in consciousness, but in reality, in life - leads a twofold life, a heavenly and an earthly life: life in the political community, in which he considers himself a communal being, and life in civil society, in which he acts as a private individual, regards other men as a means, degrades himself into a means, and becomes the plaything of alien powers." 68
\end{abstract}

The subject of Marx's criticism, Bruno Bauer, as a liberal, cannot understand the difference between political emancipation and human emancipation. He cannot see why Jews must be emancipated from the kind of society that brings about such an injustice in the first place. Furthermore, Marx points out, not only the Jewish minority but also the Christian majority need to be emancipated. Indeed, Marx insists, human emancipation cannot be attained for anyone within a civil society founded upon radical material inequalities. Everybody is alienated in "civil society," and the extension of the suffrage cannot solve such problems. $^{69}$

Marx here diagnoses a fundamental contradiction at the very core of liberal social relations: the distinction between the public and the private, along with the contradictory set of values enshrined for each distinctly-imagined sphere. As if in passing, he adds that, far from being part of the solution, the bourgeois state is actually part of the problem.

In Marx's critique of the limits of "political emancipation" there is embedded a critique of the category of nation as a mystified, illusory basis for political community. The unity of the nation always fictive, masking and transfiguring the profane power of the few into sacred form, even tans-substantiating it into the general will. Or more evocatively still, the nation as sacred vestment in which the profane naked power exercised by the agents of the bourgeois state is cloaked. 
At the same time, and perhaps more centrally, the critique of the limits of "political emancipation" entails a critique of the limits of representative democracy. A critique only occasionally recalled by post-Marxists these days, though further elaborated and forcefully articulated by Perry Anderson, who has argued in no uncertain terms:

\footnotetext{
"Parliament, elected every four or five years as the sovereign expression of popular will, reflects the fictive unity of the nation back to the masses as if it were their own self-government. The economic divisions within the 'citizenry' are masked by the juridical parity between exploiters and exploited, and with them the complete separation and non-participation of the masses in the work of parliament." 70
}

Faith in the nation, faith in the bourgeois state, faith in juridical equality, faith in representative democracy, all exposed as mystifications and as irrational delusions. Marx's critique of the category of the nation is thus subsumed under the rubric of a more comprehensive critique of mystification. Belief in "political emancipation," like belief in other ethereal myths and abstractions, equally vulnerable to Marx's general critique of religious consciousness. In Marx's own formulation:

\footnotetext{
"The members of the political state are religious owing to the dualism between individual life and species-life, between the life of civil society and political life. They are religious because men treat the political life of the state, an area beyond their real individuality, as if it were their true life. They are religious insofar as religion here is the spirit of civil society, expressing the separation and remoteness of man from man." ${ }^{\prime 71}$
}

If the project of "political emancipation" necessarily entails the consummation of alienation and the perpetuation of webs of mystified consciousness, the project of human emancipation to which Marx was committed requires precisely the opposite: a thoroughgoing process of demystification. A reverse inversion of the social world. The myths and fables long told to justify and manufacture consent to the looting, the wars, and the lies, mystifications which insidiously invade the consciousness of victimizers and victimized alike - these myths and fables need to come crashing down, Marx insists. 
How to precipitate the crash? By subjecting all dominant worldviews and interpretations to "ruthless criticism" - in Marx's words "ruthless both in the sense of not being afraid of the results it arrives at and in the sense of being just as little afraid of conflict with the powers that be." Ironically enough, given the subsequent conversion of MarxismLeninism into one of the great political religions of the twentieth century, Marx himself stressed that such a ruthlessly critical posture demanded opposition to "raising any dogmatic banner" whatsoever. According to Marx, the task of critical theory was largely deconstructive in spirit. Its main purpose not the propagation of a new dogma; to the contrary, Marx prescribes, "we must try to help the dogmatists to clarify their propositions for themselves."72

\section{The Nation as Artefact}

Hegemonic nationalist myths about the "organic" or "natural" ontology of nations notwithstanding, most leading scholars of nationalism nevertheless insist that the nation is "artefact," like the state, a work of art, even the result of "conscious efforts by leaders."73 On this point, Hobsbawm concurs with Linz, emphasising the "element of artefact, invention, and social engineering which enters into the making of nations." ${ }^{74}$ And Gellner concurs with both - in denouncing as myth the idea of "nations as a natural, God-given way of classifying men," and in claiming to have uncovered instead the sobering reality that nationalism "sometimes takes pre-existing cultures and turns them into nations, sometimes invents them, and often obliterates pre-existing cultures." ${ }^{75}$ Or, even more polemically, when Gellner insists that 
"[n]ationalism is not the awakening of nations to self-consciousness: it invents nations where they do not exist."76

Anderson has famously objected to this latter formulation of "nation as invention," on the grounds that it connotes "fabrication" and "falsity," rather than "imagining" and "creation," and thus implies a juxtaposition between "false" and "true" communities. He is certainly right that it does connote and imply such things; but this is hardly grounds for dismissing the cogency of the metaphor. Anderson insists that communities are not to be distinguished by their "truth" or "falsity," since "all communities larger than primordial villages of face-to-face contact (and perhaps even these) are imagined."77 However, just because nearly all communities are "imagined" does not mean that all claims to community are equally "true" or compelling. Claims of community can be distinguished not only by the "style" in which they are imagined; they can also be adjudicated among in terms of the particular interests and particular agendas advanced in the name of some general will.

This is the crux of Rosa Luxemburg's intransigent case against the principle of "national self-determination." For Luxemburg, such a principle seems to presume "uniform social political whole" that in any class-divided society can never be presumed, indeed there are bound to "exist within each nation classes with antagonistic interests and 'rights'."78 The point can be made more generally, in a way less constricted by the narrow class bias built into classical historical materialism. In contexts riven by ethno-racialised, gendered, and class divides, any appeal to national community and national belonging is bound to be embedded within broader struggles to reproduce or transforming existing constellations of power relations. 
Anderson objects to the treatment of nationalism as if it were a mere "ideology," akin to "liberalism" or "fascism." He likens it instead to a broad cultural system such as "kinship" or "religion."79 But the attempt to distinguish religion and kinship from mere "ideology" suggests a peculiarly narrow concept of the latter, and one that certainly cuts against the grain of the well-trodden terrain of not only Marx's but Freud's or Nietzsche's famous critiques of religious consciousness as a paradigmatic case of "false consciousness," not to mention feminist critiques of patriarchy and of discursive tropes that reify the gendered division of labour through appeals to categories like "family-values."

Even if one rejects the idea that all manifestations of religious consciousness can be reduced to or dismissed as opiate, fantasy, or outlet for ressentiment, certainly some, perhaps even most, modes of religious consciousness are vulnerable on at least one of these counts. ${ }^{80}$ What's more, not only is all religious consciousness certainly ideological when the term is used in the broad sense as entailing a comprehensive world view; so too are nearly all manifestations of religious consciousness ideological in the narrower sense of being ubiquitously marshalled in concrete political struggles to reproduce or transform existing constellations of power relations.

\section{The Nation, the Family, and Love}

The other category to which Anderson compares the nation in his attempt to render it beyond susceptibility to ideology critique is that of "kinship." The attempt to liken nationalism to "kinship" is especially problematic because it reifies and reproduces perhaps the quintessential nationalist trope or presumption - what David Theo Goldberg has referred to 
as its "abstract presumption of familialism." This presumption of the "familiar," that "I am like them," and therefore that we must be "familially connected," of course, ultimately implies - "if often silently" - a negation of those branded as nationally or racially other, those "differentiated and disconnected." 81

The "familial" analogy is central to the imagining of national community, which helps to explain the oft-observed emotive force of appeals to the nation, as well as the close affinities between nationalism and patriarchy. ${ }^{82}$ Anderson chides critics of "Nationalism with a capital N" for focusing too much on all the murders committed in the name of the nation, and focusing too little on the effectiveness of appeals to the nation at inducing a willingness to sacrifice and even to die for the sake of one's country. He also insists that critics of nationalism too often conflate nationalism with racism, too often try to depict it as motivated exclusively by hate, and too infrequently emphasise the links between nationalism and the emotion of love. ${ }^{83}$

Anderson would pose the question: how can the nation, if it is a community based on the emotion of love, be dismissed as an "ideology," as but a manifestation of false consciousness? Freud remains on this count most instructive, as Sarah Ahmed has reminded. "Love makes the subject vulnerable, exposed to, and dependent on another," and is "linked profoundly to the anxiety of boundary formation," whereby what is not me and what is me to some extent even merge. ${ }^{84}$ Love is perhaps the ultimate form of desire; as such, it is ubiquitously infused with projections of ideals. "Desire creates an ideal object." 85 And thus the potential for love to bleed into an acute form of false-consciousness, self-destructiveness, even self-loathing. As Ahmed insists: "[e]ven though love is a demand for reciprocity, it is also an emotion that lives with the failure of that demand often through an intensification of its 
affect (so, if you do not love me back, I may love you more as the pain of the non-loving is the sign of what it means not to have this love." ${ }^{86}$ Likewise, witness the frequent invocation of love in justifications for staying the course and enduring abusive familial relationships. Like a masochistic battered wife who continues to love her husband, to stand by her man despite repeated infidelities and transgressions, one can "love the nation out of hope and with nostalgia for how it could have been," one can "keep loving rather than recognizing that the love that one has given has not and will not be returned." ${ }^{87}$

What's more, the connection between the "national idea" and "national ideals" is such that perceived failure to live up to or "embody" such "ideals" serves to justify exclusion and marginalization. Indeed, the untrustworthy "others" are cast out, as foils, even scapegoated for national failings. ${ }^{88}$ In the face of the failure of the nation to return the love, i.e. to deliver on the emancipatory promises so frequently associated with it, "defensive narratives" can quickly surface. All too easily, the "failure of return is 'explained' by the presence of others," the ungrateful, the unpatriotic, those who do not belong. Thus the ubiquity of lurking projected shadows, of racialized "others," of those symbolically and materially marginalized and excluded, of the "wretched," of those who serve to fix the boundaries of the body politic, of those imagined to intrude like a virus. ${ }^{89}$ Those from other countries; those without country. No imagined self without imagined others. The discourses of destiny and contamination, it turns out, cannot be so easily decoupled.

Ultimately, love and grief are inextricably intertwined. A human who one loves is a human whose death will be grieved, whose death is worth grieving. And so, in the ideology of national belonging, as Ahmed - following Butler - points out, co-nationals' lives are elevated and imagined as "grievable;" and ritualized expressions of national grief in the wake 
of the death of "co-nationals" has the effect of reproducing and inducing the recognition, "that could have been me." 90

Love of nation, like love of family, never takes place in a vacuum. Instead, as the emotional expression of identification and desire, it is always shot through with power relations. More specifically, shot through with intimately intertwined systems of class, ethnoracialised, and gender domination. As such, appeals for loyalty to the nation, demands for sacrifice in its name, can only be adequately understood, much less evaluated, in context that is, by illuminating how such appeals are "incorporated," and how they affect the balance of concrete forces engaged in concrete and overlapping political struggles to reproduce and/or transform existing constellations of material and social power relations.

\section{The Nation and Ideology Critique}

Anderson is perhaps correct to insist - contra Luxemburg - that national consciousness is not necessarily an impediment to emancipatory political goals, nor an alternative to class consciousness, nor necessarily reducible to "false consciousness." ${ }^{91}$ But he is wrong to suggest that nationalist movements cannot be adequately understood through an interpretive lens emphasizing the specifically "ideological" dimension of the phenomenon, in the narrow sense; that is, through an analytic of ideology critique..$^{92}$

Anderson is right to insist as well that the categories and preconditions of "national consciousness" are deeply rooted in the structure of contemporary society, including technologies of social communication and basic features of capitalist as well as state-socialist 
social-property relations. No doubt, one of the great virtues of Anderson's book is the breadth and complexity of the causal account he provides.

Indeed, Anderson compellingly links the emergence of "national consciousness" to broader conditions of epistemic possibility - including crucially the rise of the scientific worldview in Europe, the process of secularisation, and the consubstantial emergent dominant conception of time as "homogenous and empty," all mediated through the machinations of print capitalism..$^{93}$

The notion of "homogenous, empty time" comes from Walter Benjamin, upon whom Anderson's causal account relies significantly. In this respect, it is more than a little ironic that he attempts to divorce "nationalism" from "fascism," by elevating the former to the status of "cultural system," while demoting the latter to the level of mere ideology, alongside the likes of liberalism. For Benjamin offered a prescient and piercing early diagnosis of "mass society," and even "the society of the spectacle"- a condition (a) underpinned and propelled forward by transformations in art and in the "mass media" in the age of mechanical reproduction; and (b) intimately intertwined with the rise of fascism.

According to Benjamin, fascism is best understood as "an attempt to organize the newly created proletarian masses without affecting the property structure," promising them salvation not by giving the masses "their right," their due, but instead merely giving them "a chance to express themselves, resulting in the "introduction of aesthetics into political life." Benjamin hones in especially on the significance of the Futurists' glamorization and glorification of the alleged beauty of war, adducing it as evidence of the extent of human "self-alienation" experienced in "mass society." In his words: "Mankind's ... self-alienation 
has reached such a degree that it can experience its own destruction as an aesthetic pleasure of the first order." 94

Benjamin, like Freud, held the modern experience to be centered principally on "shock." As Buck-Morss has explained: "In industrial production no less than modern warfare, in street crowds and erotic encounters, in amusement parks and gambling casinos, shock is the very essence of modern experience." Under such conditions, "response to stimuli without thinking has become necessary for survival." Consciousness comes to serve largely as a "shield" and a "buffer," protecting the organism by preventing the retention of external stimuli from being "impressed as memory," even "isolating present consciousness from past memory." The depth of memory thus flattened, "experience is impoverished." 95 This "crisis in cognitive experience" is in turn linked to the cultivation of narcissism, a narcissism which "functions as an anaesthetizing tactic against the shock of modern experience," which is "appealed to daily by the image-phantasmagoria of mass culture," and which renders fertile "the ground from which fascism" can spring forth. ${ }^{96}$

But Anderson's attempt to divorce "nationalism" from "fascism" is ultimately unconvincing, regardless of one's views about Benjamin. ${ }^{97}$ The experience of the first half of the twentieth century in Europe cannot be brushed aside so easily, as if a fluke. Hobsbawm's comparative evidence is compelling. In the fifty years or so leading up to the outbreak of Continental-cum-World War in 1914, all versions of nationalism that "came to the fore" had one thing in common: "a rejection of the new proletarian socialist movements, not only because they were proletarian, but also because they were, consciously and militantly internationalist, or at the very least non-nationalist." Indeed, in this crucial prelude to the unprecedented level of human destruction of the so-called Great War, mass nationalism 
competed directly for appeal amidst a host of rival ideologies - "notably, class-based socialism" - which, tragically, it vanquished. ${ }^{98}$

\section{Conclusion}

This article has defended the proposition that the nation is best conceived as a hegemonic project. The nation as category is analytically distinct from the state; even so, it is a category with a very definite history, in which it has been inextricably intertwined with the legitimation of "modern" and of "modernizing" states, perhaps particularly but certainly not only in Europe. ${ }^{99}$

The article traces the rise and problems associated with the doctrine of "selfdetermination." It builds on Hobsbawm's account of the impractical and ultimately disastrous consequences of the attempt to render state frontiers convergent with the frontiers of ethnicity and language in Interwar Europe, before turning to advocate a recuperation of more critical alternatives to the ossified Leninist-cum-Stalinist dogmas about self-determination within the classical Marxist tradition.

The repertoire of critical reflections on the limits and alternatives to national "selfdetermination" from the classical Marxist tradition can of course be amplified much further. Most importantly, a host of other relevant and critical voices can be recovered, especially voices reflecting the experiences of struggles against colonialism and the challenges faced in the post-colonial world. Voices such as that of Frantz Fanon, who warned early on against the "pitfalls of national consciousness;" or that of Julius Nyerere, who insisted upon distinguishing between "the task of the nationalist," which he considered "simply to rouse 
the people to a confidence in their power to protest," on the one side, and "the real freedom which socialism represents," on the other, "a very different thing."100

Such a task would certainly take us beyond the limits of this article. Indeed, it would require us to transcend the epistemological confines of much of the theoretical and comparative scholarship on nationalism in the English language, which remains all-toocomplacently anchored in a Euro-centric outlook and focus. The historical configuration of relations between states and nations no doubt vary in significant ways in and across postcolonial contexts. ${ }^{101}$

In practice, self-determination has rarely resembled anything approximating human emancipation. Instead, the slogans of national belonging and appeals to the general will of the national community have served to advance particular interests - indeed, to cover over and conceal inequities, injustices, and exclusions within and between the boundaries of the imagined body politic. Thus the urgency of the task of deconstructing the category of the nation, of rendering it susceptible to "ruthless criticism," i.e. to the method and practice of ideology critique. This requires locating the source and delineating the resonance of any and all appeals to the nation within concrete struggles to reproduce or transform existing constellations of power relations. Comprehending the ideological efficacy of recourse to national community and national ideals does not require downplaying or denying the affinities among nationalism, racism, and fascism. To the contrary, such comprehension requires recognition and critical analysis of the intimate connections between the group emotions of love and hate, the discourses of destiny and contamination, and the political logics of belonging and exclusion. 
${ }^{1}$ The term "hegemonic project" I take from Bob Jessop, State Power (Cambridge, UK: Polity Press, 2008), which he defines, following Gramsci, as a project "to secure the political, intellectual, and moral leadership of the dominant class(es)," p.12. For the genealogy of the term hegemony, see P. Anderson, "The Antinomies of Antonio Gramsci," New Left Review, 100 (Nov. 1976 - Jan. 1977), pp.578; and E. Laclau and C. Mouffe, Hegemony and Socialist Strategy (London: Verso, 1985), ch.1.

${ }^{2} \mathrm{G}$. Therborn, The Ideology of Power and the Power of Ideology (London: Verso, 1980).

${ }^{3}$ R. Brubaker, Nationalism Reframed (Cambridge: Cambridge University Press, 1996); and Laclau and Mouffe, op. cit., p.67.

${ }^{4} \mathrm{M}$. Hroch, "From National Movement to Fully Formed Nation: the Nation-Building Process in Europe," in G. Balakrishnan, ed. Mapping the Nation (London: Verso, 1993), pp.78-97; S. Rokkan, Nation-Building and Citizenship (New York: Anchor Books, 1969); J. Linz, "State building and nation building," European Review 1:4 (1993), pp.355-369; S. Rokkan, "Nation-Building: A Review of Models and Approaches," Current Sociology, Vol. 19, No. 3 (1971): pp.7-38; and S. Rokkan, "Dimensions of State Formation and Nation-Building: A Possible Paradigm for Research on Variations within Europe," in Charles Tilly, ed. The Formation of National States in Western Europe (Princeton, NJ: Princeton University Press, 1975), pp. 562-600.

${ }^{5}$ Brubaker, op. cit.

${ }^{6}$ E. Gellner, Nations and Nationalism (Ithaca, NY: Cornell University Press, 1983), p.55.

${ }^{7}$ For classic analyses that focus on the "programmatic" level, see E. Kedourie, Nationalism. $4^{\text {th }}$ edn (Oxford: Blackwell, 1993); and H. Kohn, Nationalism: Its Meaning and History (Princeton, NJ: Van Nostrand, 1955). For an analysis focusing on the level of the "banal," see M. Billig, Banal Nationalism (London: Sage Publications, 1995).

${ }^{8}$ Gellner (1983), op. cit., p.1.

${ }^{9}$ P. Bourdieu, "Social Space and Symbolic Power," Sociological Theory, 7(1) (1989), pp.14-25.

${ }^{10}$ On Gramsci's treatment of the "national question," see E. Nimni, Marxism and the National Question: Thoeretical Origins of a Political Crisis (London: Pluto Press, 1991), ch. 4. For relevant applications of Gramsci's theory of hegemony to the analysis of nationalist dynamics, see I. Lustick, Unsettled States, Disputed Lands (Ithaca: Cornell University Press, 1993); M. Beissinger, Nationalist Mobilization and the Collapse of the Soviet State (Cambridge: Cambridge University Press, 1996); T. Miley, "Blocked Articulation and Nationalist Hegemony in Catalonia," Regional \& Federal Studies 23(1) (2013), pp. 7-26; and T. Miley, "Democratic Representation and the National Dimension in Catalan and Basque Politics," International Journal of Culture, Politics, and Society 27 (2014), pp. 291-322.

${ }^{11}$ D. Porpora, "Cultural Rules and Material Relations," Sociological Theory, 11(2) (1993), pp.212-229. Quote from p.217.

12 Ibid., p.222.

${ }^{13}$ c.f. H. Bhabha, "DissemiNation: time, narrative, and the margins of the modern nation," in $\mathrm{H}$. Bhabha, ed. Nation and Narration (London: Routledge, 1990), p.294.

${ }^{14}$ Linz, op. cit., p.355. See also H. Seton-Watson, Nations and States: An Enquiry into the Origins of Nations and the Politics of Nationalism (Boulder, CO: Westview Press, 1977).

${ }^{15}$ R. Bendix, Kings or People. Power and the Mandate to Rule (Berkeley: University of California Press, 1978), p.605, fn.1.

${ }^{16}$ See also P. Anderson, Lineages of the Absolutist State (London: New Left Books, 1974); T. Ertmann, Birth of the Leviathan (Cambridge: Cambridge University Press, 1997); G. Poggi, The Development of the Modern State (Stanford, CA: Stanford University Press, 1978); and M. Weber, "Politics as a Vocation," in H. G. Gerth and C. Wright Mills, eds., From Max Weber: Essays in Sociology (New York: Oxford University Press, 1958), pp.129-156.

${ }^{17}$ Linz, op. cit., p.356.

${ }^{18}$ B. Anderson, Imagined Communities (London: Verso, 1983/2006).

${ }^{19}$ E. Hobsbawm, Nations and Nationalism since 1780 (Cambridge, MA: Cambridge University Press, 1990), p.5. 
${ }^{20} \mathrm{Ibid}$., p.8. On the "essentially contested" nature of alternative definitions of the nation, see also C. Calhoun, "Nationalism and Ethnicity," Annual Review of Sociology 19 (1993), pp.211-239, especially pp.215-216.

${ }^{21}$ M. Weber, "The Nation," in Economy and Society, Vol. 2 (Berkeley, CA: The University of California Press, 1978), pp.921-926.

22 J. Linz and A. Stepan, Problems of Democratic Transition and Consolidation (Baltimore, MD: The Johns Hopkins University Press, 1996), p.21.

${ }^{23}$ Linz, op. cit., p.359.

${ }^{24}$ Ibid., p.356. See also W. Connor, "When Is a Nation?," Ethnic \& Racial Studies 13(1) (1990), pp. 92103; D. D. Laitin, Nations, States, and Violence (Oxford: Oxford University Press, 2007); M. Hechter, Containing Nationalism (Oxford: Oxford University Press, 2001); and E. Hobsbawm (1990), op. cit. Cf. A. D. Smith, Nationalism and Modernism (London: Routledge, 1988), for the classic "anti-modernist" counter-argument, which would locate the origins of the nation much deeper in history. More recently, however, Smith has significantly amended his original position to accommodate the "modernist" thesis. See his Ethno-symbolism and Nationalism: A Cultural Approach (London: Routledge, 2009), and J. Hutchison and M. Guibernau, eds., History and National Destiny: EthnoSymbolism and its Critics (London: Blackwell, 2004).

${ }^{25}$ Linz and Stepan, op. cit., pp.20-21. However, on "proto-national" sentiments associated with loyalty to a common monarch, see L. Greenfeld, Nationalism: Five Roads to Modernity (Cambridge, MA: Harvard University Press, 1992).

${ }^{26}$ D. Conversi makes a persuasive case that nationalism should be considered one of the chief longterm political consequences of the French Revolution, and emphasises in particular the role of the Napoleonic wars in its spread. See "Modernism and Nationalism," Journal of Political Ideologies 17(1) (2012), pp.13-34.

${ }^{27}$ B. Anderson, op. cit., p.7.

${ }^{28}$ E. Hobsbawm (1990), op. cit., pp.9-10.

${ }^{29}$ J. Breuilly, Nationalism and the State (Chicago, IL: The University of Chicago Press, 1994); and C. Tilly, "States and Nationalism in Europe 1492-1992," Theory and Society 23(1) (1994), pp.131-146.

${ }^{30}$ E. Hobsbawm, The Age of Empire (New York: Pantheon Books, 1987), pp.148-149.

${ }^{31}$ E. Weber, Peasants into Frenchmen (Palo Alto, CA: Stanford University Press, 1976).

${ }^{32}$ E. Hobsbawm (1987), op. cit., p.150.

${ }^{33} \mathrm{Ibid}$., p.88. For a more sanguine version of the link between nationalism and democracy, see $T$. Nairn, "The Modern Janus," in The Break-Up of Britain (London: New Left Books, 1977), pp.317-350; and T. Nairn, Faces of Nationalism: Janus Revisited (London: Verso, 1998).

${ }^{34}$ For the role of the educational system in the construction of the French nation, see E. Weber, op. cit. Gellner (1983), op. cit., goes so far as to claim that "the monopoly over legitimate education is now more important than the monopoly of legitimate violence" in the maintenance of social order (p.34). For an account of patterns of post-communist collapse that focuses on the legacies of precommunist nationalization in the educational system, see K. Darden and A. Grzymala-Busse, "The Great Divide: Literacy, Nationalism, and the Post-Communist Collapse," World Politics 59 (Oct. 2006), pp.83-115.

${ }^{35} \mathrm{E}$. Weber, op. cit., also emphasises the role of conscription in the making of the French nation. On the relation between mobilization for war and 'nationalization' more generally, see D. Conversi, "Homogenisation, Nationalism, and War. Should We Still Read Ernest Gellner?," Nations and Naitonalisms, 13(3) (2007), pp.371-394; and D. Conversi, "'We Are All Equals!' Militarism, Homogenisation, and 'Egalitariansim' in Nationalist State-Building (1789-1945)," Ethnic and Racial Studies 31(7) (2008), pp. 1286-1314.

${ }^{36}$ In P. Anderson, "Imperium," The New Left Review, 83, Sept.-Oct. 2013, pp.5-111. Quoted on p.10.

${ }^{37}$ Gellner (1983), op. cit., p.1. For the seminal treatment of the history of the principle of selfdetermination, see A. Cobban, The Nation State and National Self-Determination (New York: Thomas Y. Crowell Co., 1969). 
${ }^{38}$ E.H. Carr, The Bolshevik Revolution 1817-1923. Volume 1 (New York: Norton, 1950), p. 412.

${ }^{39}$ Breuilly, op. cit., ch.5; and O. Pflanze, "Nationalism in Europe, 1848-1871," The Review of Politics 28(2) (Apr., 1966), pp.129-143.

${ }^{40} \mathrm{Linz}$, op. cit., p.357. On the liberalism originally associated with romantic nationalism in Germany, see B. Vick, "The Origins of the German Volk: Cultural Purity and National Identity in Nineteenth Century Germany," German Studies Review 26(2) (2003), pp. 241-256.

${ }^{41}$ Linz, op. cit., p.357. On nationalism in nineteenth-century Italy, see L. Riall, The Italian Risorgimento: State, Society, and National Unification (London: Routledge, 2004). On Bismarckian "nation-building," see O. Pfanze, Bismarck and the Development of Germany (3 vols., Princeton, NJ: Princeton University Press, 1990); and G. Eley, "Society and Politics in Bismarckian Germany," German History 15(1) (1997), pp.101-132.

${ }^{42}$ On the application of the principle of self-determination in the peace treaties at the end of the First World War, see Cobban, op. cit., ch.3.

${ }^{43}$ E. Hobsbawm (1990), op. cit., pp.132-133. For a similar judgment about the lessons of the interwar European experience, see J. Coackley, "National Minorities and the Government of Divided Societies: A Comparative Analysis of Some European Evidence," European Journal of Political Research 18 (1990), pp.437-456.

${ }^{44}$ Gellner (1983), op. cit., p.2.

${ }^{45}$ For discussions of the moral legitimacy and sociological dynamics of contemporary appeals for national self-determination, see A. Buchanan, "Theories of Secession," Philosophy and Public Affairs, 26(1) (1997), pp.31-61; V.O. Bartkus, The Dynamic of Secession (Cambridge: Cambridge University Press, 1999); L. C. Buchheit, Secession (New Haven, CT: Yale University Press, 1978); J. Linz, "Cautionary and Unorthodox Thoughts about Democracy," in D. Chalmers and S. Mainwaring, eds. Problems Confronting Contemporary Democracies (Notre Dame, IN: Notre Dame University Press, 2012), pp.227-252; R. Bauböck, "Paradoxes of Self-Determination and the Right to Self-Government", in C. Eisgruber and A. Sajo, eds., Global Justice and the Bulwarks of Localism: Human Rights in Context (Leiden: Martinus Nijhoff Publishers, 2005), pp. 101-128; and D. Ronen, The Quest for SelfDetermination (New Haven, CT: Yale University Press, 1979).

${ }^{46}$ For Lenin's most significant writing on the right to national self-determination, see H. B. Davis, Nationalism and Socialism (New York: Monthly Review Press, 1967), ch.8.

${ }^{47}$ Hobsbawm (1990), op. cit., p.148.

${ }^{48}$ S. Cohen, Bukharin and the Bolshevik Revolution (New York: Vintage, 1975), p.36.

${ }^{49}$ Carr, op. cit., p.422; O. Bauer, The Question of Nationalities and Social Democracy (Minneapolis, MN: University of Minnesota Press, 2000 [1924]). For summary views of the Austro-Marxist position in historical context, see also S. Avineri, "Marxism and Nationalism," Journal of Contemporary History 26(3/4) (1991), pp.636-657; J. Coakley, "Approaches to the Resolution of Ethnic Conflict: The Strategy of Non-Territorial Autonomy," International Political Science Review 15(3) (1994), pp.297-314; M. Löwy, "Marxists and the National Question," New Left Review 96 (1976), pp.81-100; R. Munck, "Marxism and Nationalism in the Era of Globalization," Capital \& Class 34(1) (2010), pp.45-53; E. Nimni, op. cit., ch.5-7; and J. L. Talmon, The Myth of the Nation and the Vision of Revolution (Berkeley, CA: University of California Press, 1981), part 3.

${ }^{50}$ R. Luxemburg, Rosa, "The National Question and Autonomy," in Horace B. Davis, ed., The National Question. Selected Writings by Rosa Luxemburg (London: Monthly Review Press, 1976 [1909]), pp.109110. For scholarly treatments of Luxemburg on the "national question," see H. B. Davis, "Introduction. The Right of Self-Determination in Marxist Theory - Lenin versus Luxemburg," in Davis, op. cit., pp.948; N. Ito, "Is the National Question an Aporia for Humanity? How to Read Rosa Luxemburg's 'The National Question and Autonomy'," Research in Political Economy 26 (2010), pp.3-68; Löwy, ibid., pp.85-89; J.P. Nettl, Rosa Luxemburg, 2 Volumes (London: Oxford University Press, 1966), especially Appendix II, pp.842-862; A. Nye, Philosophia: The Thought of Rosa Luxemburg, Simone Weil, and Hannah Arendt (New York: Routledge, 1994), pp.18-23; Talmon, ibid., part 2; A. K. Shelton, "Rosa Luxemburg and the National Question," East European Quarterly XXI(3) (Sept. 1987), pp.297-303; and 
D. Whitehall, "A Rival History of Self-Determination," European Journal of International Law 27(3) (2016), pp.719-743.

${ }^{51}$ Quoted in Cohen, op. cit., pp.36-37. See also R. V. Daniels, The Conscience of the Revolution (New York: Simon and Schuster, 1969), pp.32-33.

52 On Lenin's collaboration with Stalin in the formulation of Bolshevik policy on nationalities, see I. Deutscher, Stalin: A Political Biography (London: Penguin Books, 1990), ch.4-6. For a succinct discussion of the Bolshevik doctrine of self-determination before and during the revolution, see Carr, op. cit., note B, pp.410-428. For subsequent Soviet practice, see G. Smith, ed., The Nationalities Question in the Soviet Union (London: Longman, 1991); R. G. Suny, the Revenge of the Past: Nationalism, Revolution, and the Collapse of the Soviet Union (Stanford, CA: Stanford University Press, 1993), ch. 4; and I. Bremmer, "Reassessing Soviet Nationalities Theory," in I. Bremmer and R. Taras, eds., Nations and Politics in the Soviet Successor States (Cambridge: Cambridge University Press, 1993), pp.3-28. On the treatment of the "national question" in other Marxist-Leninist states, see W. Connor, The National Question in Marxist-Leninist Theory and Strategy (Princeton, NJ: Princeton University Press, 1984).

${ }^{53}$ Multiple promising efforts have been made along such lines. For a recent powerful defense of Luxemburg's stance on self-determination, see D. Whitehall, op. cit. From a perspective closer to anarchism, see M. Bookchin, "Nationalism and the 'National Question'," Society and Nature 2(2) (1994), pp.8-36. For two recent engagements with African anti-colonial thinkers that seek to recover imaginings of decolonization and "self-determination" alternative to the form of the "independent" nation-state, see F. Cooper, Africa in the World: Capitalism, Empire, Nation-State (Cambridge, MA: Harvard University Press, 2014); and G. Wilder, Freedom Time: Negritude, Decolonization, and the Future of the World (Durham, NC: Duke University Press, 2015). Perhaps the most creative attempt to redefine "self-determination" as radical democracy against the nation-state has come from the imprisoned leader of the Kurdish Freedom Movement, Abdullah Ocalan. See his Democratic Confederalism (London: Transmedia Publishing Ltd., 2011); and Manifesto for a Democratic Civilization (Cologne: New Compass Press, 2015).

${ }^{54}$ For such allegations, see S. Avineri (1991), op. cit.; R. Debray, "Marxism and the National Question,"New Left Review, 105 (1977), pp.20-42; Löwy, op. cit.; Nairn (1977), op. cit.; and R. Munck, Marxism and Nationalism: The Difficult Dialogue (London: Zed Books, 1986).

${ }^{55}$ Quoted in R. Szporluk, Communism and Nationalism (Oxford: Oxford University Press, 1988), pp.5758.

${ }^{56}$ K. Marx and F. Engels, "Manifesto of the Communist Party," in R. Tucker, ed., The Marx-Engels Reader. Second Edition (New York: Norton, 1978 [1848]), pp.469-500. Quote from p.488.

${ }^{57}$ Ibid., pp.476-477.

58 J. L. Talmon, op. cit., p.27.

${ }^{59}$ See K. Anderson, Marx at the Margins. On Nationalism, Ethnicity, and Non-Western Societies (Chicago, IL: University of Chicago Press, 2016); and E. Brenner, Really Existing Nationalisms: A PostCommunist View from Marx and Engels (Oxford: Clarendon Press, 1995). However, for a cogent critique of the chauvinistic German prejudices clouding both Marx's and especially Engel's approach to matters associated with nationhood, nationalism, race, and ethnicity, see C. Robinson, Black Marxism (Chapel Hill, NC: The University of North Carolina Press, 2000), pp.52-61.

${ }^{60}$ E. Hobsbawm, "Introduction," in K. Marx and F. Engels, The Communist Manifesto (London: Verso, 2012 [1848]).

${ }^{61}$ See Hobsbawm (1987), op. cit.

${ }^{62}$ For reactions to the Bolshevik revolution among Marxists in the West, see M. van der Linden, Western Marxism and the Soviet Union (Leiden: Brill, 2007), ch.2. For the views of Lenin and Trotsky on the prospects for world revolution, see E. Van Ree, "Socialism in One Country: A Reassessment," Studies in East European Thought 50(2) (1998), pp.77-117; and I. Deutscher, The Prophet Armed. Trotsky 1879-1921 (London: Verso, 2003).

${ }^{63}$ See Deutscher (1990), op. cit.; and Daniels, op. cit., pp.398-412. 
${ }^{64}$ Kolakowski, quoted in Szporluk, op. cit., p.59.

${ }^{65}$ Ibid., p.60.

${ }^{66} \mathrm{~K}$. Marx, "On the Jewish Question," in R. Tucker, ed., The Marx-Engels Reader. Second Edition (New York: Norton, 1978 [1843]), pp.26-52. Quotes from pp.36, 29.

${ }^{67}$ Ibid., p.32.

68 Ibid., p.34.

${ }^{69}$ See D. McLellan, Karl Marx: A Biography (London: MacMillan, 1995), pp.72-77; and S. Avineri, “Marx and Jewish Emancipation," Journal of the History of Ideas 25(3) (1964), pp.445-450.

70 P. Anderson, "The Antinomies of Antonio Gramsci," The New Left Review, 100 (Nov.-Dec. 1976), pp.5-78. Quote from p.28.

${ }^{71}$ Marx (1843/1978), op. cit., p.39.

72 K. Marx, "Letter to Ruge"

https://www.marxists.org/archive/marx/works/1843/letters/43_09.htm.

${ }^{73}$ Linz, op.cit., p.360.

${ }^{74}$ Hobsbawm (1990), op. cit., p.10.

${ }^{75}$ Gellner (1983), op. cit., pp.48-49.

${ }^{76}$ E. Gellner, Thought and Change (Chicago: University of Chicago Press, 1978 [1964]), p.169.

${ }^{77}$ B. Anderson, op. cit., p.6.

${ }^{78}$ Quoted in Nettl, op. cit., p.849.

${ }^{79}$ B. Anderson, op. cit., p.5.

${ }^{80}$ See J. Marsh, op. cit., pp.158-190.

${ }^{81}$ D.T. Goldberg, The Threat of Race. Reflections on Racial Neoliberalism (Oxford: Wiley-Blackwell, 2009), pp.5-6.

${ }^{82}$ On the affinities between familial and national ideologies, see also E. Balibar, "The Nation Form: History and Ideology," in E. Balibar and I. Wallerstein, Race, Nation, Class. Ambiguous Identities (London: Verso, 1991), pp. 86-106. On the relation between nationalism and gender oppression, see N. Yuval-Davis, Gender \& Nation (London: SAGE, 1997); A. McClintock, “'No Longer in a Future Heaven' Nationalism, Gender, and Race," in Imperial Leather: Race, Gender, and Sexuality in the Colonial Contest (New York, NY: Routledge, 1995), pp.352-389: R. Radhakrishnan, "Nationalism, Gender, and the Narrative of Identity," in A. Parker, M. Russo, et. al., eds., Nationalisms \& Sexualities (New York, NY: Routledge, 1992), pp.77-95; and S. Walby, "Woman and Nation," International Journal of Comparative Sociology XXXIII(1-2) (1992), pp.81-100. On the relation between nationalism and hegemonic norms of masculinity, see P. Holden, Autobiography and Decolonization. Modernity, Masculinity, and the Nation-State (Madison, WI: The University of Wisconsin Press, 2008); and G. L. Mosse, "Nationalism and Sexuality in Nineteenth-Century Europe," Culture and Society XX(5) (Jul-Aug 1983), pp.75-84.

${ }^{83}$ B. Anderson, op. cit., pp.5, 141.

${ }^{84}$ S. Ahmed, The Cultural Politics of Emotion (New York: Routledge, 2014 [2004]), p.125

85 Ibid., p.127.

${ }^{86}$ Ibid., p.130.

${ }^{87}$ Ibid., p.131.

${ }^{88}$ See E. Balibar, "Racism and Nationalism," in E. Balibar and I. Wallerstein, op. cit., pp.37-68; G. Eley and R. Suny, "Introduction: From the Moment of Social History to the Work of Cultural Representation," in G. Eley and R. Suney, eds., Becoming National: A Reader (Oxford: Oxford University Press, 1996) pp.3-37, p.28; S. Hall, "Introduction: Who Needs Identity?," in S. Hall and P. Du Gay, eds., Questions of Cultural Identity (London: SAGE, 1996); and K. Tölölyan, "The Nation-State and its Others: In Lieu of a Preface," Diaspora: A Journal of Transnational Studies, 1(1) (1991), pp.3-7.

${ }^{89}$ E. Balibar, op. cit., pp.42-43; P. Gilroy, "Nationalism, History and Ethnic Absolutism," History Workshop Journal 30 (Autumn 1990), pp.114-120; and D. Mertz, "The Racial Other in Nationalist Subjectivations: A Lacanian Analysis," Rethinking Marxism 8(2) (1995), pp.77-88. 
${ }^{90}$ Ahmed, op. cit., p.130; J. Butler, Precarious Lives. The Powers of Mourning and Violence (London: Verso, 2006).

${ }^{91}$ For a sophisticated defence of the irreducibility of national identity to "false-consciousness," see R. Smith, Stories of Peoplehood: The Politics and Morals of Political Membership (Cambridge: Cambridge University Press, 2003).

${ }^{92}$ For a forceful argument that "nationalism" is best conceived as a component of the broader dominant ideology of "modernism," see D. Conversi (2012), op. cit. Along compatible lines, M. Freeden has made a strong case that "nationalism" is most accurately considered an "embellisher" and "sustainer" of such host ideologies as "liberalism," "socialism," or "fascism." See "Is Nationalism a Distinct Ideology?," Political Studies, XLVI (1998), pp.748-765. However, pace Anderson, neither Conversi's nor Freeden's arguments would seem to imply that nationalism should be considered "beyond" or "above" ideology critique.

${ }^{93}$ B. Anderson, op. cit., pp.24, 37.

${ }^{94}$ W. Benjamin, "The Work of Art in the Age of Mechanical Reproduction," in Illuminations (London: Pimlico, 1999 [1920]), pp.234-235.

95 S. Buck-Morss, "Aesthetics and Anaesthetics: Walter Benjamin's Artwork Essay Reconsidered," October, Vol. 62, Autumn 1992, pp.3-41. Quote from p.16.

${ }^{96}$ Ibid., pp.37, 41.

${ }^{97}$ On the impossibility of divorcing nationalism from fascism, see also Conversi (2012), op. cit.

${ }^{98}$ Hobsbawm (1990), op. cit., pp.122-123.

${ }^{99}$ See Conversi (2012), op. cit.

${ }^{100}$ F. Fanon, The Wretched of the Earth (London: Penguin Books, 2001 [1961]); H. Davis, op. cit.

101 For exemplary examinations of some such configurations, see R. Aminzade, Race, Nation, and Citizenship in Postcolonial Africa: The Case of Tanzania (Cambridge: Cambridge University Press, 2014); N. P. Applebaum, A. S. MacPherson, et. al., eds., Race and Nation in Latin America (Chapel Hill, N.C.: University of North Carolina Press, 2003); L. W. Barrington, ed., After Independence: Making and Protecting the Nation in Postcolonial and Postcommunist States (Ann Arbor, MI: The University of Michigan Press, 2006); J. F. Bayart, The State in Africa. The Politics of the Belly (London: Longman, 1993); P. Chatterjee, The Nation and its Fragments: Colonial and Post-Colonial Histories (Princeton, NJ: Princeton University Press, 1993); P. Duara, "Historicizing National Identity, or Who Imagines What and When," in G. Eley and R. Suny, op. cit., pp. 151-177; F. Halliday, Nation and Religion in the Middle East (London: Saqi Books, 2000); M. Mamdani, Citizen and Subject. Contemporary Africa and the Legacy of Late Colonialism (Princeton, NJ: Princeton University Press, 1996); and A. Stepan, J. Linz, and Y. Yadav, Crafting State Nations. India and Other Multinational Democracies (Baltimore, MD; The Johns Hopkins University Press, 2011). 